\title{
ANALISIS HYGIENE SANITASI DEPOT AIR MINUM ISI ULANG DI WILAYAH KECAMATAN WONOMULYO KABUPATEN POLMAN
}

\author{
${ }^{1}$ Evi Wulandari \\ ${ }^{1}$ Jurusan Kebidanan Program Studi Diploma III Kebidanan \\ ${ }^{2}$ Bagian Lembaga Penelitian dan Pengabdian Masyaraktat STIKes Bina Bangsa Majene, \\ Email: eviwulandarihimawan@gmail.com
}

\begin{abstract}
ABSTRAK
Kehidupan manusia tidak bisa lepas dari kebutuhan terhadap air bersih, manusia sangat membutuhkan air bersih untuk memenuhi kehidupan sehari-hari, diantaranya untuk memenuhi kebutuhan minum. Air minum merupakan kebutuhan vital bagi kehidupan manusia dan saat ini semakin sulit di temukan dikarenakan pencemaran limbah rumah tangga dan limbah industri terhadap sumber air permukaan maupun air tanah. Hasil Riskesdas 2013 menunjukkan bahwa proporsi rumah tangga berdasarkan jenis sumber air minum di Indonesia terbesar pada sumur gali terlindung sebesar 22,5\%, kemudian air isi ulang sebesar $21 \%$ dan sumur bor/pompa sebesar 12,8\%. Proporsi rumah tangga yang menggunakan air isi ulang dan air kemasan mempunyai persentase yang cukup besar.

Penelitian ini bertujuan untuk menganalisis Hygiene sanitasi depot air minum isi ulang di Kec. Wonomulyo Kab. Polewali Mandar tahun 2015 dengan jenis penelitian Survey Deskriptif. Pengambilan Sampel dengan Teknik pengambilan sampel secara Exhaustive sampling/sampling jenuh yaitu seluruh depot air minum di Wilayah Kecamatan Wonomulyo. Pengumpulan data melalui proses wawancara berupa lembar observasi dengan metode ceklist dengan analisis data menggunakan program komputer spss jenis analisis data analisis univariat.
\end{abstract}

Berdasarkan hasil analisa Hygiene sanitasi depot air minum isi ulang di Kec. Wonomulyo Kab. Polewali Mandar tahun 2015, menunjukkan bahwa Distribusi DAMIU berdasarkan hygiene karyawan terdapat $13(72 \%)$ tidak sehat. sedangkan yang sehat sebanyak 5 (28\%), Distribusi DAMIU berdasarkan sanitasi bangunan terdapat $9(50 \%)$ memenuhi syarat sedangkan yang tidak memenuhi syarat sebanyak 9 (50\%) dan Distribusi DAMIU berdasarkan peralatan terdapat 18 yang memenuhi syarat sebanyak $18(100 \%)$.

Hasil penelitian ini menunjukkan perlunya memperhatikan Hygiene karyawan dan bagunan depot air minum isi ulang agar air minum isi ulang dapat terjamin kualitasnya.

Kata Kunci : Hygiene sanitasi depot air minum isi ulang 


\section{PENDAHULUAN}

Kehidupan manusia tidak bisa lepas dari kebutuhan terhadap air bersih, manusia sangat membutuhkan air bersih untuk memenuhi kehidupan sehari-hari, diantaranya untuk memenuhi kebutuhan minum. Hasil Riskesdas 2013 menunjukkan bahwa proporsi rumah tangga berdasarkan jenis sumber air minum di Indonesia terbesar pada sumur gali terlindung sebesar 22,5\%, kemudian air isi ulang sebesar $21 \%$ dan sumur bor/pompa sebesar 12,8\%. Proporsi rumah tangga yang menggunakan air isi ulang dan air kemasan mempunyai persentase yang cukup besar. Hal ini terjadi seiring dengan kemajuan teknologi serta semakin tinggi tingkat kesadaran masyarakat terhadap kesehatan terutama dalam pemenuhan kebutuhan air bersih untuk minum, sementara itu persediaan air tanah yang selama ini menjadi sumber utama air minum telah semakin berkurang, rumah tangga kini mulai beralih kepada produk air minum dalam kemasan/isi ulang. Produk ini merupakan salah satu solusi untuk konsumsi air minum karena produk dapat langsung diminum karena telah melalui proses produksi.

Pentingnya kegunaan air dalam sehari-hari bagi manusia tentunya akan diimbangi dengan penyedian sumber air yang dapat menyediakan air yang baik dari segi kualitas maupun kuantitas. Kondisi kualitas dan kuantitas air sangat rendah di berbagai kota di indonesia sehingga tidak mampu memenuhi kebutuhan dan harapan penduduk, menyebabkan air menjadi benda ekonomi yang mahal sehingga masyarakat mencari alternatif untuk mendapatkan air yang layak di minum, yaitu air minum dari depot air minum isi ulang (DAMIU) dengan harga yang lebih murah. Akan tetapi dalam perkembangannya kualitas dari produk DAMIU tidak terjaga sehingga berpotensi membahayakan bagi kesehatan masyarakat. Untuk itu diperlukan pengawasan terhadap DAMIU oleh dinas kesehatan. Pengawasan yang dilakukan mencakup kondisi sanitasi lingkungan (tempat cuci tangan, bangunan dan kebersihan lingkungan pengolahan, hygiene karyawan, pembuangan sampah dan limbah) dan kualitas bakteriologis pada DAMIU (Munandar, 2013)

Hasil Riskesdas 2013 menunjukkan bahwa proporsi rumah tangga berdasarkan jenis sumber air minum di Indonesia terbesar pada sumur gali terlindung sebesar $22,5 \%$, kemudian air isi ulang sebesar $21 \%$ dan sumur bor/pompa sebesar 12,8\%. Proporsi rumah tangga yang menggunakan air isi ulang dan air kemasan mempunyai persentase yang cukup besar. Hal ini terjadi seiring dengan kemajuan teknologi serta semakin tinggi tingkat kesadaran masyarakat terhadap kesehatan terutama dalam pemenuhan kebutuhan air bersih untuk minum, sementara itu persediaan air tanah yang selama ini menjadi sumber utama air minum telah semakin berkurang, 
rumah tangga kini mulai beralih kepada produk air minum dalam kemasan/isi ulang. Produk ini merupakan salah satu solusi untuk konsumsi air minum karena produk dapat langsung diminum karena telah melalui proses produksi.

Penelitian yang dilakukan Harvard University selama 22 tahun, akhirnya menambah temuan betapa bahayanya Air Mineral yang mengandung Flourida yaitu dapat mengurangi IQ anak-anak. Studi telah menemukan bahwa fluorida berlebih didalam tubuh dapat menyebabkan gejalagejala sebagai berikut : Hiperaktif atau kelesuan, Gangguan otot, Radang sendi, Demensia, Tidak aktifnya 62 enzim dan menghambat lebih dari 100 Enzim, Menghambat pembentukan antibodi, Kematian sel, Patah tulang, serta Beberapa jenis kanker dalam tulang (Guntoro, 2014).

Menurut Gravani dan Marriot (2006) Hygiene bisa dikatakan sebagai upaya kesehatan dengan cara memelihara dan melindungi kebersihan individu subyeknya, sedangkan sanitasi dapat dikatakan sebagai upaya kesehatan yang dilakukan dengan memelihara dan melindungi kebersihan lingkungan dari subyeknya. Kontaminasi bakteri pada air minum bisa diakibatkan oleh terkontaminasinya air baku oleh berbagai bahaya fisik, kimia, biologi, maupun radioaktif, tangan karyawan peralatan pengolah AMIU, dan pakaian pekerja, terutama jika keadaan sanitasi dan Hygiene buruk. Peningkatan kualitas dan ketersediaan air, pembuangan ekskreta dan Hygiene perseorangan menjadi hal yang penting untuk mengurangi transmisi penyakit melalui jalur pajanan fekal-oral (WHO, 2011). Pada penelitian yang dilakukan Lyus (2005) menyatakan bahwa dari 25 depot yang diamati, 7 depot (28\%) yang diamati tidak memenuhi syarat Hygiene perorangan, 5 depot (20\%) tidak memenuhi syarat sanitasi depot air minum, 3 depot (12\%) tidak memenuhi syarat ruang pengisian air minum, dan 14 depot (56\%) tidak memenuhi syarat sanitasi ruang pencucian galon.

Berdasarkan hasil penelitian Pradana dan Marsono (2013) menunjukkan bahwa kualitas air minum isi ulang ditunjang oleh cara pemeliharaan peralatan produksi. Prosedur pemeliharaan alat dari masing-masing depot air minum isi ulang diperoleh melalui wawancara dan penggunaan kuesioner. Hasil uji laboratorium dari 8 depot air minum isi ulang ada yang belum memenuhi parameter Total Koliform sebanyak 5 depot. Berdasarkan hasil kuesioner 5 depot tersebut termasuk dalam kategori cukup, yang berarti masih kurang dalam melakukan pemeliharaan alat. Hasil survey rekam medik Puskesmas Wonomulyo, Depot Air Minum Isi Ulang di Wilayah Kec. Wonomulyo Kab. Polman berjumlah 18 DAMIU. Dari hasil pengamatan peneliti dilapangan, nampak beberapa DAMIU kurang memenuhi syarat terkait dengan hygiene karyawan nampak beberapa karyawan tidak mencuci tangan dan menggunakan 
pakaian kerja saat melanyani konsumen begitupun dengan sanitasi bangunan dan peralatan yang kurang mendapat perhatian dari pemilik DAMIU.

Berdasarkan uraian di atas, dapat disimpulkan bahwa hygiene sanitasi yang buruk akan berefek pada produksi air minum pada DAMIU sehingga peneliti tertarik untuk mengetahui hygiene karyawan, sanitasi bangunan, dan sanitasi peralatan Depot Air Minum Isi Ulang di Wilayah Kec. Wonomulyo Kab. Polewali Mandar tahun 2015.

\section{METODE PENELITIAN}

Rancangan Penelitian

Jenis penelitian yang digunakan dalam penelitian ini adalah Survey Deskriptif. Subyek penelitian adalah DAMIU di Wilayah Kecamatan Wonomulyo, Kabupaten Polman Propinsi Sulbar. Adapun metode pengumpulan data yaitu diperoleh dari hasil wawancara langsung dengan menggunakan lembar observasi kepada responden dan diperoleh dari DAMIU di Wilayah Kec. Wonomulyo Kab. Polman.

Populasi dan Tehnik Sampel

Populasi sebanyak 18 DAMIU di wilayah Kecamatan Wonomulyo, Kabupaten Polman, Propinsi Sulbar dan sampel dalam penelitian ini adalah seluruh depot air minum di Wilayah Kecamatan Wonomulyo berjumlah 18 DAMIU dan Teknik pengambilan sampel secara Exhaustive sampling/sampling jenuh (pengambilan sampel diambil seluruhnya untuk dijadikan sampel penelitian).

\section{Instrumen Penelitian}

Alat-alat yang digunakan berupa lembar observasi dengan metode ceklist. Lembar observasi yang gunakan bersumber dari peraturan yang ditetapkan untuk DMIU.

Analisa data

pengolahan data menggunakan SPSS dan penyajian data dilakukan dalam bentuk tabel gambar dan disertai dengan penjelasan (narasi)

\section{HASIL PENELITIAN}

Distibusi DAMIU berdasarkan hygiene karyawan Dari hasil observasi didapatkan 18 depot air minum isi ulang yang pada karyawanya didapatkan tidak sehat sebanyak 13 (72\%) dan sehat sebanyak 5 (28\%). Distibusi DAMIU berdasarkan Sanitasi Bangunan. Dari hasil observasi depot air minum isi ulang sebanyak 18 terdapat sanitasi bangunan yang memenuhi syarat sebanyak 9 (50\%) dan tidak memenuhi syarat sebanyak 9 (50\%). Distibusi DAMIU berdasarkan Peralatan. Dari hasil observasi depot air minum isi ulang sebanyak 18 terdapat peralatan yang memenuhi syarat sebanyak $18(100 \%)$.

\section{PEMBAHASAN}


Peneliti melakukan observasi pada 18 depot air minum isi ulang yang berada di wonomulyo. Pada tanggal 7 juli 2015 peneliti melakukan observasi pada jam 8 pagi karena rata-rata beroperasi pada jam 8 pagi sampai dengan jam 7 malam pada depot air minum isi ulang peneliti menemukan adanya suatu kekurangan pada hygiene karyawan terdapat 13 depot air minum isi ulang dikategorikan tidak sehat dan terdapat 5 yang sehat.

Berdasarkan hasil penelitian depot air minum isi ulang diKecamatan Wonomulyo Kabupaten Polewali Mandar Distribusi depot air minum isi ulang berdasarkan hygiene karyawan terdapat 18 depot dari 18 depot air minum isi ulang 13 tidak sehat, dan sebanyak 5 sehat.

Berdasarkan hasil penelitian depot air minum isi ulang di Kecamatan Wonomulyo Kabupaten Polewali Mandar Distribusi depot air minum isi ulang berdasarkan sanitasi bangunan terdapat 18 depot dari 18 air minum isi ulang 9 depot yang sanitasi bangunan memenuhi syarat, dan 9 tidak memenuhi syarat.

Berdasarkan hasil penelitian depot air minum isi ulang di Kecamatan Wonomulyo Kabupaten Polewali Mandar Distribusi depot air minum isi ulang berdasarkan peralatan terdapat 18 DAMIU dan 18 memenuhi syarat.

Berdasarkan Gambaran Hygiene sanitasi DAMIU Terdapat 5 hygiene karyawan yang sehat pada depot (Sa,
Si, Hg, Mi, Ms) dan 13 yang tidak sehat pada depot (Gg, Em, Sd, Ss, Hi, Jh, Gs, Aa, Rn, Hh, ih, Sy, Bn), Terdapat 9 sanitasi bangunan yang memenuhi syarat pada depot (Bn, Ih, Aa, Em, Sd, Ss,Hi, Jh, Hg) dan 9 yang memenuhi syarat pada depot (Sa, Si, Hg, Mi, Ms, Gs, Rn,Hh, Sy), dan Terdapat 18 peralatan yang memenuhi syarat pada depot $(\mathrm{Sa}, \mathrm{Si}$, $\mathrm{Hg}$, Mi, Ms, Gg, Em, Sd, Ss, Hi,Jh, Gs, Aa, Rn, Hh, Ih,Sy,Bn).

Penelitian ini sejalan dengan yang dilakukan Lyus (2005) menyatakan bahwa dari 25 depot yang diamati, 7 depot (28\%) yang diamati tidak memenuhi syarat Hygiene perorangan, 5 depot (20\%) tidak memenuhi syarat sanitasi depot air minum, 3 depot (12\%) tidak memenuhi syarat ruang pengisian air minum, dan 14 depot (56\%) tidak memenuhi syarat sanitasi ruang pencucian galon.

\section{KESIMPULAN DAN SARAN}

Distribusi DAMIU berdasarkan hygiene karyawan terdapat 13 (72\%) tidak sehat. sedangkan yang sehat sebanyak 5 (28\%). Distribusi DAMIU berdasarkan sanitasi bangunan terdapat $9(50 \%)$ memenuhi syarat sedangkan yang tidak memenuhi syarat sebanyak 9 (50\%). Distribusi DAMIU berdasarkan peralatan terdapat 18 yang memenuhi syarat sebanyak 18 (100\%).

Disarankan kepada pemilik depot agar memperhatikan bangunan atau lokasi agar tidak terjadi pencemaran diantaranya lokasi yang berada di 
daerah yang bebas dari pencemaran, bangunan harus kuat, mudah dibersihkan, lantai kedap air, dinding kedap air, atap langit-langit harus kuat, anti tikus, memiliki pintu yang kuat dan berfungsi dengan baik pencahayaan cukup, ventilasi ada dan memberikan pertukaran udara yang baik memiliki fasilitas sanitasi dasar Air Minum Isi Ulang

\section{DAFTAR PUSTAKA}

Athena. 2004. Kandungan Bakteri Total

Coli dan Escherichia

Coli/Fecal Coli Air Minum dari DAMIU di Jakarta, Tanggeran, dan Bekasi. Buletin Penelitian Kesehatan, Vol. 32, No. 4.

Chandra Budiman. 2007. kesehatan lingkungan. Cetakan Pertama. EGC : Jakarta

Gravani RB dan Mariot NG. 2006. Principle Of Food Sanitation. Pringer : New York.

Guntoro, 2014. Penulisan Populer. kualitasdan-kelayakan-air-minum-isiulang.(online)

Joko T. 2010. Unit Produksi Dalam Sistem Penyediaan Air Minum. Graha Ilmu : Yogyakarta

Keputusan Menteri Perindustrian Dan Perdagangan. 2004. Tentang Persyaratan Teknis Depot Air Minum Dan Perdangangan. Jakarta : Departemen Kesehatan RepublikIndonesia.

Kemenkes 2013. Profil kesehatan indonesia. Kementerian Kesehatan Republik Indonesia.

Klinik pengobatan alami. 2013. indonesiadibodohkan-dengan-air mineral.(online) (https://.wordpress.com/2013/ 09/07/ diakses tanggal 26/05/2015)
Lyus. 2005. Tinjauan Terhadap

Fakto-Faktor Yang

Berhubungan Dengan

Terjadinya Kontaminasi

Bakteriologi Eschericia Coli

Dan Coliform Pada Depot-

Depot Air Minum Isi Ulang

Di Wilayah Jakarta Pusat

Yang Menjadi Industri Binaan

Suku Dinas Kesehatan

Masyarakat Pusat Tahun

2004. Skripsi program sarjana FKM UI Depok.

Munandar. 2013. Teknik Pengawasan Depot Air Minum Isi Ulang

(Damiu)

Mulia R. 2005. Kesehatan

Lingkungan. Cetakan Pertam.

Yogyakarta ; Graha Ilmu.

Pracoyo, 2004. Penelitian

Bakteriologik Isi Ulang di daerah Jabodetabek. Depkes.

Pradana Yoga Ardy dan Marsono

Bowo Djoko. 2013. Uji

Kualitas Air Minum Isi Ulang di Kecamatan Sukodono, Sidoarjo Ditinjau dari Perilaku dan Pemeliharaan Alat. Jurnal Teknik Pomits Vol. 2, No. 2. Jurusan Teknik Teknik Lingkungan, Fakultas Teknik Sipil dan Perencanaan, Institut Teknologi Sepuluh Nopember (ITS).

Peraturan Menkes RI. 2014. Tentang Higiene Sanitasi Depot Air

Minum. Menteri kesehatan republik indonesia.

Peraturan Menkes RI. 2010. Tentang

Kualitas air minum.

Departemen Kesehatan

Republik Indonesia : Jakarta

Peraturan Menkes RI. 2010. Tentang

Tata Laksana Pengawasan

Kualitas Air Minum.

Departemen Kesehatan

Republik Indonesia : Jakarta

Riskesdas. 2013. Badan Penelitian

Dan Pengembangan 
Kesehatan Kementerian

Kesehatan RI.

Soemirat Juli. 2011. Kesehatan

lingkungan. Cetakan

kedelapan. Gadjah Mada

University Press: Yogyakarta.

World health organization. 2011.

Gundelmens for drinking

water Quality 4th edition.

Gevana. Switzerland. 